\title{
Genetic Variability in the Isolates of Rhizoctonia solani Kühn, the Causal Agent of Sheath Blight of Rice by Using RAPD Markers
}

\author{
P. Nagaraju ${ }^{1 *}$ and M.K. Naik ${ }^{2}$ \\ ${ }^{1}$ Plant Pathology, AICRP on Groundnut, University of Agricultural Sciences, \\ Dharwad-580 005, Karnataka, India \\ ${ }^{2}$ Department of Plant Pathology, University of Agricultural Sciences, \\ Raichur-584 104, Karnataka, India \\ *Corresponding author
}

\begin{tabular}{|c|c|}
\hline & A B S T R A C T \\
\hline Keywords & \multirow{4}{*}{$\begin{array}{l}\text { Thirty two Rhizoctonia solani isolates were studied for molecular variability by } \\
\text { RAPD technique at the Institute of Agri-biotechnology, University of Agricultural } \\
\text { Sciences, Dharwad, India during } 2007 \text {. The results indicated that, there were } \\
\text { differences in RAPD profiles of } 32 \text { isolates of } R \text {. solani with two random primers } \\
\text { OPB-15 and OPD-13. The primer OPB- } 15 \text { and OPD- } 13 \text { produced } 248 \text { PCR } \\
\text { products of molecular weight ranging from } 300 \text { bp to } 600 \text { bp in different isolates } \\
\text { with diverse amplicon. To test the resolving ability of these primers, cumulative } \\
\text { RAPD profiles generated by the random primers were analyzed by UPGMA. All } \\
\text { the isolates shared minimum of } 60 \text { per cent and above similarity among } \\
\text { themselves. The cumulative analysis of } 32 \text { isolates showed four groups at } 75 \text { per } \\
\text { cent genetic similarity level. }\end{array}$} \\
\hline $\begin{array}{l}\text { Genetic variability, } \\
\text { Rhizoctonia solani } \\
\text { isolates, RAPD } \\
\text { markers, Sheath } \\
\text { blight, Rice. }\end{array}$ & \\
\hline Article Info & \\
\hline $\begin{array}{l}\text { Accepted: } \\
\text { 04 September } 2017 \\
\text { Available Online: } \\
10 \text { October } 2017\end{array}$ & \\
\hline
\end{tabular}

\section{Introduction}

Sheath blight of rice caused by Rhizoctonia solani Kühn, once a minor disease, has become one of the major diseases inflicting heavy yield losses in most of the Asian countries. Rice sheath blight was first reported from Japan by Miyake in 1910, subsequently it was reported throughout the temperate and tropical rice growing areas. The occurrence of the disease in India was first reported by Paracer and Chahal (1963) from Gurdaspur in Punjab. Now its occurrence is observed in almost all rice growing states of India with an estimated loss of grain yield to the extent of 5.20 to 50 per cent (Das and Mishra, 1990). Among $R$. solani isolates there exists high variations with respect to cultural, morphological and pathogenic characters. The pathogen produces two types of mycelium, straight and branched, and lobate, of which only the latter type is infectious.

The lesion is covered by lobate mycelium while the straight type may extend beyond without causing infection (Ou et al., 1973). While such variations are to be explored further by studying at pathogenic and molecular level to give logical conclusion. 
Hence, there is a need to take up variability studies employing robust sampling and molecular assay methods.

\section{Materials and Methods}

Thirty two isolates of $R$. solani were collected from different rice growing areas of India during kharif seasons in 2006 and 2007. During the roving survey carried out in kharif 2006 and 2007, a large number of sheath blight infected rice samples were collected from different places viz., Tungabhdra Project (TBP) area of Raichur (Sindhanur, Manvi, Raichur), Bellary (Sirguppa) and Koppal (Gangavati) districts in north eastern Karnataka and Mandya, Mysore, Shimoga in southern Karnataka.

These typical sheath infected samples were subjected to standard tissue isolation technique under aseptic condition using laminar flow to obtain Rhizoctonia solani culture. The infected tissue of the sheath were cut into small bits of 1-2 mm size and surface sterilized in 1:1000 mercuric chloride $\left(\mathrm{HgCl}_{2}\right)$ solution for one minute and washed repeatedly twice in sterile distilled water to remove the traces of mercuric chloride before transferring them to sterile potato dextrose agar (PDA) slants under aseptic conditions. The slants were incubated at temperature of $27 \pm 1{ }^{\circ} \mathrm{C}$ and observed for fungal growth. The culture, thus obtained was purified by hyphal tip isolation method. In addition isolates of $R$. solani were also obtained from Coimbatore (Tamil Nadu), Hissar (Haryana), Kapurthala and Amritsar (Punjab) and Hyderabad (Andhra Pradesh). The sources and identity of thirty two isolates $R$. solani obtained from different region are presented in table 1 .

\section{Hyphal tip isolation}

This method was followed for maintaining pure culture, since the fungus is known to be highly heterozygous. Hyphal tip isolation was done on two per cent water agar plates. Dilute mycelial suspensions $\left(10^{-6}\right)$ were prepared in sterile distilled water. One $\mathrm{ml}$ of such suspension was spread uniformly on water agar plates and observed for mycelia under microscope isolated mycelial bit was transferred on PDA plates, under aseptic conditions. The PDA plates were incubated at a temperature of $27+1{ }^{\circ} \mathrm{C}$ and observed for fungal growth. No sectoring was observed in any of the plates and all of them were found identical in their growth and colony characters on their respective plate. Hence, it was taken as pure pathogenic culture and was maintained for further studies.

The $R$. solani isolates were studied for molecular variability by RAPD technique at the Institute of Agri-biotechnology, University of Agricultural Sciences, Dharwad, India. Total genomic DNA from the fungal isolates was extracted by Hexa decyl trimethyl Ammonium Bromide (CTAB) method as follows.

\section{Total genomic DNA extraction}

Genomic DNA was extracted by using the CTAB (Hexa decyl trimethyl ammonium bromide, Sigma Chemical Co., St. Louis, USA) method of Lee and Taylor (1990). Then assessment of DNA quality and quantity was done.

\section{Primers and PCR amplification}

Thirty Operon oligonueleotide random primers (Operon Technologies, USA) were screened for amplification of genomic DNA of $R$. solani. Among these only two primers OPB-15 and OPD-13 were selected based on their repeatability and used for amplification.

The PCR amplifications were performed by using thermal cycler (Biometra) programmed for initial DNA denaturation at $94{ }^{0} \mathrm{C}$ for 5 min followed by 45 cycles at $94{ }^{\circ} \mathrm{C}$ for $1 \mathrm{~min}$, 
$45{ }^{\circ} \mathrm{C}$ for $1 \min 72{ }^{\circ} \mathrm{C}$ for 2 min and a final cycle was performed at $72{ }^{\circ} \mathrm{C}$ for $7 \mathrm{~min}$. All the amplified DNA products were resolved by electrophoresis on agarose gel $(1.5 \%)$ in TAE ( $1 \mathrm{X})$ buffer, stained with ethidium bromide and photographs were taken by using gel documentation system.

\section{Data analysis}

DNA amplicon resulting from PCR were scored for the presence as ' 1 ' or absence as ' 0 ' at various molecular weight sizes in the form of binary matrix. Data were analyzed to obtain Jaccard's coefficients among the isolates by using NTSYS-pc (version 2.0; Exeter Biological Software, Setauket, NY). Jaccard's coefficients were clustered to generate dendrograms by using the SAHN clustering programme, selecting the unweighted pair-group method with arithemetic average (UGMA) algorithm in NTSYS-pc (Rohlf, 1993).

\section{Results and Discussion}

Out of initial 30 random decamer primers amplified for nucleotide sequence, only two random primers were selected based on their repeatability of polymorphism in all 32 isolates of $R$. solani. Number of countable amplicon produced by these random primers are presented in table 2 and Plate 1.

The differences in RAPD profiles of 32 isolates of $R$. solani with two random primers OPB-15 and OPD-13 are given in table 2. The primer OPB-15 and OPD-13 produced 248 PCR products of molecular weight ranging from $300 \mathrm{bp}$ to $600 \mathrm{bp}$ in different isolates with diverse amplicon.

To test the resolving ability of these primers, cumulative RAPD profiles generated by the random primers were analyzed by UPGMA. All the isolates shared minimum of 60 per cent and above similarity among themselves.
The cumulative analysis of 32 isolates showed four groups at 75 per cent genetic similarity level.

As per dendrogram cluster analysis (Figure 1 ), all the 32 isolates were grouped into two major clusters such as $\mathrm{C} 1$ and $\mathrm{C} 2$, wherein cluster $\mathrm{C} 1$ consists of 15 isolates and cluster C2 consists of 17 isolates (Table 3). The main cluster $\mathrm{C} 1$ has been further grouped into two sub-clusters $\mathrm{C} 1-1$ and $\mathrm{C} 1-2$. Cluster C1-1 consists of seven isolates namely RS-1, RS-5, RS-9, RS-15, RS-24, RS-16, RS-22 and the cub-cluster C1-2 consists of 8 isolates namely RS-25, RS-21, RS-31, RS-30, RS-14, RS-29, RS-20 and RS-13. The main cluster C2 consists of 17 isolates. The sub-cluster under main cluster $\mathrm{C} 2-1$ consists of 10 isolates namely RS-2, RS-3, RS-4, RS-32, RS-18, RS17, RS-28, RS-23, RS-11 and RS-10, whereas the sub-cluster C2-2 consists of seven isolates namely RS-6, RS-26, RS-7, RS-8, RS-27, RS19 and RS-12.

Genetic variability in $R$. solani isolates from various places have been studied earlier using RAPD markers. Prasad et al., (2004) reported that Fusarium oxysporum isolates (including various identified formae speciales) are grouped along with other formae specialcs of $F$. oxysporum in the study. Assessment of molecular variability based on micro-satellite markers using universal rice primers indicated clearly that $F$. oxysporum is heterogeneous, highly diverse and most of the formae speciales have evolutionary biology linked to $F$. oxysporum. In most instances, different species of Fusarium viz., $F$. graminearum, $F$. pallidoroseum and $F$. chlamydosporum were grouped separately showing low genetic similarity to $F$. oxysporum. DNA banding pattern was very specific to species and formae speciales of $F$. oxysporum and other Fusarium species obtained in the study were highly useful for the differentiation of Fusarium isolates belonging to different species. 
Table.1 Source and identity of $R$. solani isolates from different rice growing regions of India

\begin{tabular}{|c|c|c|c|c|}
\hline Sl. No. & State & District & Locality & Isolates \\
\hline 1. & Punjab & Amritsar & Amritsar & RS-1 \\
\hline 2. & Punjab & Kapurthala & Kapurthala & RS-2 \\
\hline 3. & Haryana & Hissar & Hissar & RS-3 \\
\hline 4. & Tamil Nadu & Coimbatore & Coimbatore & RS-4 \\
\hline 5. & Andhra Pradesh & Hyderabad & DRR, Hyderabad & RS-5 \\
\hline 6. & Karnataka & Mandya & VC Farm & RS-6 \\
\hline 7. & & & Kirangur & RS-7 \\
\hline 8. & & & B.R.Koppalu & RS-8 \\
\hline 9. & & & Thubinakere & RS-9 \\
\hline 10. & & & Shivalli & RS-10 \\
\hline 11. & & & Kalenahalli & RS-11 \\
\hline 12. & & & M.N.Katte & RS-12 \\
\hline 13. & & & B.Hosalli & RS-13 \\
\hline 14. & & Raichur & Manvi & RS-14 \\
\hline 15. & & & Neermanvi & RS-15 \\
\hline 16. & & & Kalmala & RS-16 \\
\hline 17. & & & Rampura & RS-17 \\
\hline 18. & & Koppal & Gangavathi & RS-18 \\
\hline 19. & & & Vaddaratti & RS-19 \\
\hline 20. & & Bellary & ARS, Siruguppa & RS-20 \\
\hline 21. & & & Desnur & RS-21 \\
\hline 22. & & & Ibrahimpur & RS-22 \\
\hline 23. & & & Dadesugur & RS-23 \\
\hline 24. & & & Thekkalakote & RS-24 \\
\hline 25. & & & Halekote & RS-25 \\
\hline 26. & & & Raravi & RS-26 \\
\hline 27. & & & Araliganur & RS-27 \\
\hline 28. & & & K.Sugur & RS-28 \\
\hline 29. & & Mysore & T.N.Pura & RS-29 \\
\hline 30. & & & Gargeswari & RS-30 \\
\hline 31. & & Shimoga & Abbalagere & RS-31 \\
\hline 32. & & & Kommanahal & RS-32 \\
\hline
\end{tabular}

Table.2 Number of loci amplified by two RAPD primers in isolates of Rhizoctonia solani

\begin{tabular}{|c|c|}
\hline Random primer & Number of loci amplified \\
\hline OPB-15 & 126 \\
\hline OPD-13 & 122 \\
\hline Total loci amplified & 248 \\
\hline
\end{tabular}


Table.3 Grouping of Rhizoctonia solani isolates of rice using cluster analysis based on RAPD data

\begin{tabular}{|c|c|l|}
\hline \multicolumn{2}{|c|}{ Cluster } & \multicolumn{1}{c|}{ Isolate number } \\
\cline { 2 - 3 } C1 & C1-1 & RS-1, RS-5, RS-9, RS-15, RS-24, RS-16, RS-22 \\
\cline { 2 - 3 } & C1-2 & $\begin{array}{l}\text { RS-25, RS-21, RS-31, RS-30, RS-14, RS-29, RS-20, RS- } \\
13\end{array}$ \\
\hline \multirow{3}{*}{ C2 } & C2-1 & $\begin{array}{l}\text { RS-2, RS-3, RS-4, RS-32, RS-18, RS-17, RS-28, RS-23, } \\
\text { RS-10, RS-11 }\end{array}$ \\
\cline { 2 - 3 } & C2-2 & RS-6, RS-26, RS-7, RS-8, RS-27, RS-19, RS-12 \\
\hline
\end{tabular}

Fig.1 Dendrogram of 32 isolates of Rhizoctonia solani

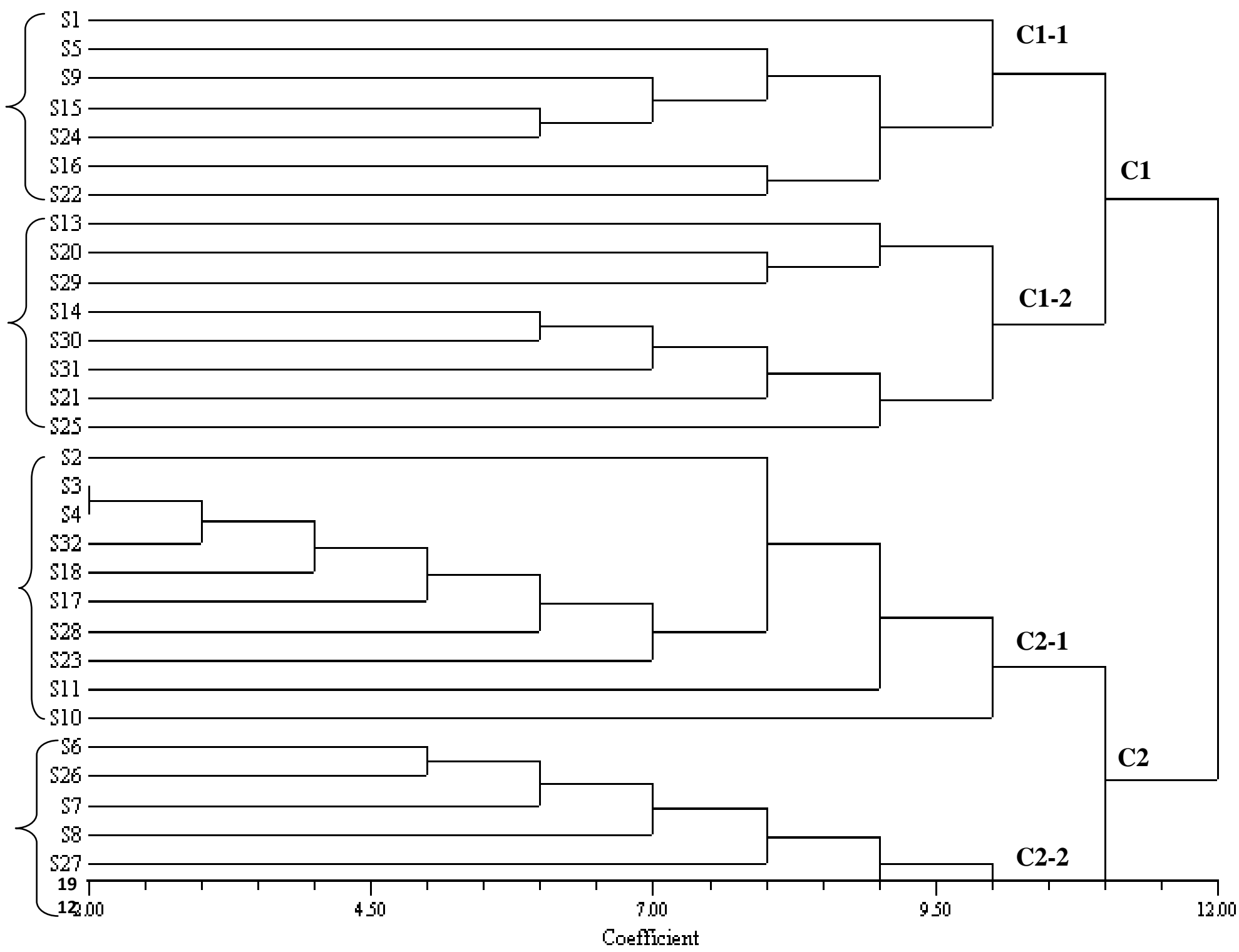




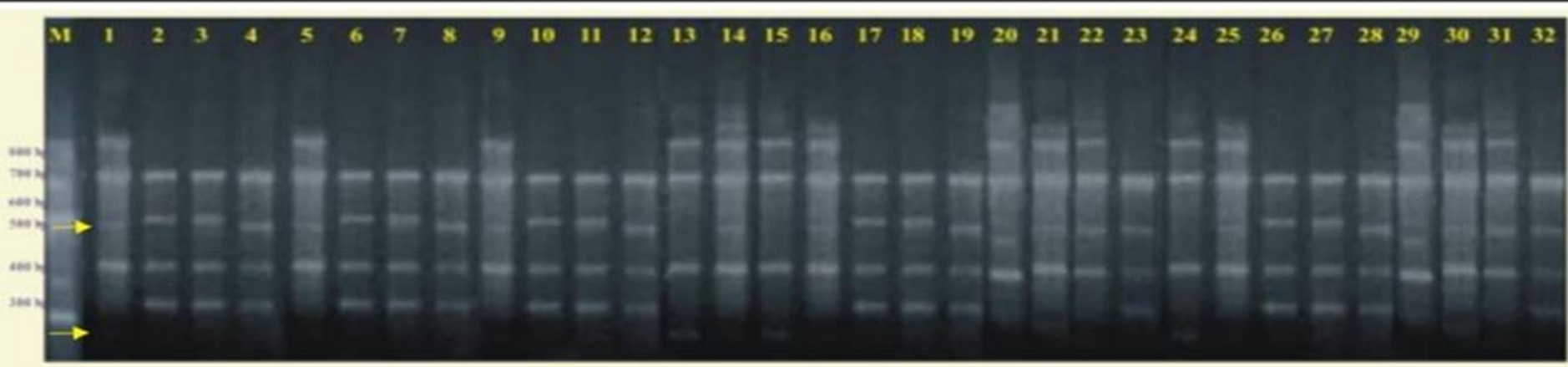

OPB-15

OPB15 marker profiles of 32 isolates of Rhizoctonia solani

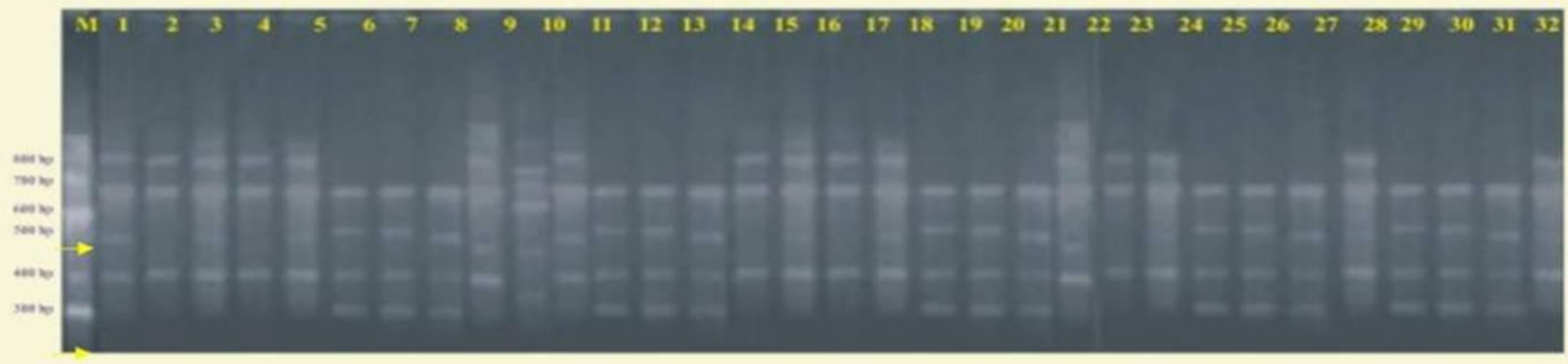

OPD-13

OPD13 marker profiles of 32 isolates of Rhizoctonia solani

Plate 1 : Molecular variability of 32 isolates of $R$. solani by RAPD analysis

The lack of a perfect state, wide intra-field variability and compatible fusion among morphologically and virulent wise dissimilar isolates indicated heterokaryosis as the major mechanism for creating inter-field variability in $R$. solani (Singh et al., 2003).

The results of our study are similar in lines with those obtained by Kistler (1997) and Gherbawy (1999) who suggested that certain $F$. oxysporium isolates within a formae speciales may be genetically less similar to each other than those isolated as nonpathogenic strains or those isolated as a group in the other formae speciales (Vilgalys and Cubeta, 1994; Banniza et al., 1996; Kistler, 1997; Koening et al., 1997; O’Donnell et al., 1998; Neeraja et al., 2002 ; Runhua et al., 2002).
From the present investigation, it was concluded that, all the isolates of $R$. solani of rice shared minimum of 60 per cent and above genetic similarity among themselves. The cumulative analysis of 32 isolates showed four groups at 75 per cent genetic similarity level. This shows the genetic variability among the $R$. solani isolates collected from different geographical regions of India.

\section{References}

Banniza, S., Ruherford, M. A., Bridge, P. D., Holderness, M. and Mordue, J. E., 1996. Biological characterization of Rhizoctonia solani in rice based cropping system. Brighton Crop Prot. Conf., Pests and Diseases, UK, 18(21): 
399-404.

Das, S. R., and Mishra, B., 1990. Field evaluation of fungicides for control of sheath blight of rice. Indian Phytopath, 43: 94-99.

Gherbawy, Y. A. M. H., 1999. RAPD profile analysis of isolates belonging to different forma speciales of Fusarium oxysporum. Cytologia, 64: 269-276.

Kistler, H. C., 1997. Genetic diversity in the plant pathogenic fungus. Fusarium oxysporum. Phytopathology, 87: 474479.

Koening, R. L., Ploetz, R. C. and Kistler, H. C., 1997. Fusarium oxysporum f. sp. Cubense consists of small number of divergent and globally distributed clonal lineage. Phytopathology, 68: 915-923.

Lee, S. B., and Taylor, J. W., 1990. Isolation of DNA from fungal mycelia and single spores. In : The PCR Protocols A Guide to Methods and Applications (Eds. M. A. Innis, D. H. Gelfand, J. J. Sniusky and T. J. White), Academic Press, New York, pp. 282-314.

Neeraja, C. N., Vijayabanu, N., Shenoy, V. V., Reddy, C. S. and Sharma, N. P., 2002. RAPD analysis of Indian isolates of rice sheath blight fungus $R$. solani. $J$. Pl. Biochem. Biotech, 11(1): 43-48.

O’Donnell, K., Cigelink, E. and Nirenberg, H. I., 1998. Molecular systematics and phylogeography of Gibberella fujikuroi: species complex. Mycologia, 90: 465493.

Ou, B. H., Bandong, J. M. and Nuque, E. L., 1973. A Hand Book of Rice Diseases in the Tropics. In: International Rice Research Conference, Los Banos, Philippines, pp. 58.

Paracer, C. S., and Chahal, D. S., 1963. Sheath blight of rice caused by Rhizoctonia solani Kuhn. A new record in India. Curr. Sci., 32: 328-329.

Prasad, R. D., Sharma, T. R., Jana, T. K., Prameela Devi, T., Singh, N. K. and Koundal, K. R., 2004. Molecular analysis of genetic variability in Fusarium species using micro satellite markers. Indian Phytopathol, 57(3): 272-279.

Rohlf, F. J., 1993. Numerical Taxonomy and Multivariate Analysis System. Version 2.11a Exeter Software, Setauket, New York, p. 208.

Runhua Yi, Liang Cheng Ye, Zhu-xiru, Zhou Erxun, Yi, R. H., Wang, C. Y., Zhu, X. R. and Zhou, E. X., 2002. Genetic diversity of rice sheath blight isolates from different rice cultivars. Chinese Rice Res. Newslett., 10(2): 7-8.

Singh, V., Singh, U. S., Singh, K. P. Majorsingh, and Anilkumar, 2003. Genetic diversity of Rhizoctonia solani isolates from rice: differentiation by morphological characteristics, pathogenicity, anastomosis behaviour and RAPD finger printing. J. Mycol. Pl. Path., 32(3): 332-344

Vilgalys, R., and Cubeta, M. A., 1994. Molecular systematics and population biology of Rhizoctonia. Ann. Rev. Phytopathol., 32: 135-155.

\section{How to cite this article:}

Nagaraju, P. and Naik, M.K. 2017. Genetic Variability in the Isolates of Rhizoctonia solani Kühn, the Causal Agent of Sheath Blight of Rice by Using RAPD Markers. Int.J.Curr.Microbiol.App.Sci. 6(10): 112-118. doi: https://doi.org/10.20546/ijcmas.2017.610.013 